\title{
PARTISIPASI MASYARAKAT DALAM PENANGGULANGAN KEBAKARAN HUTAN DAN LAHAN DI DESA LIMBUNG KECAMATAN SUNGAI RAYA KABUPATEN KUBU RAYA
}

\author{
(Community Participation In The Prevention Of Forest And Land Fires In The Unsteady Village \\ Of The Sungai Raya Sub-District Of The Kubu Raya District)
}

\author{
Rizha Melgivari, Eddy Thamrin, Emi Roslinda \\ Fakultas Kehutanan, Universitas Tanjungpura, Jalan Imam Bonjol Pontianak 78124 \\ Email: rizhamelgivari06@gmail.com
}

\begin{abstract}
Limbung Village Sungai Raya Subdistrict Kubu Raya Regency is one of the areas with a lot of peat so it is a fire-prone area. This is because the people there are still dependent on nature, no wonderland clearing is often done by burning. Fire prevention efforts in the village of Limbung carried out by Manggala Agni and MPA have not been running effectively and efficiently because there is still burning land, especially during the dry season. For prevention efforts that are expected to run effectively and efficiently, direct community participation is also needed to support prevention before more widespread fires occur. This study aims to determine the relationship of community participation in combating forest and land fires with a cosmopolitan level, level of knowledge and level of dependence on the land. This study used a survey method with interview techniques. The analysis used is descriptive analysis and Kendall Tau correlation inferential analysis. The number of samples taken was 96 people using the Slovin formula and the sampling was done by purposive sampling technique. The results showed a total score of 2852 participation and at the level of partnership according to Arnstein's theory, the level of participants tended to be low, and there were no significant differences in participation with the level of knowledge, the level of cosmopolitan and the level of dependence on the land.
\end{abstract}

Keyword: community, fires, forest, land, participation.

\section{PENDAHULUAN}

Kebakaran hutan merupakan salah satu bentuk bencana yang sering terjadi. Dampak negatif yang ditimbulkan oleh kebakaran hutan cukup besar mencakup kerusakan ekologis, menurunnya keanekaragaman hayati, merosotnya nilai ekonomi hutan dan produktivitas tanah, perubahan iklim mikro maupun global, dan asapnya mengganggu kesehatan masyarakat serta mengganggu transportasi baik darat, laut dan udara. Kebakaran hutan dan lahan juga terjadi setiap tahunnya dengan cakupan luas dan jumlah titik api (hot spot) yang bervariasi.Pengendalian kebakaran hutan adalah berbagai kegiatan yang dilakukan untuk mencegah dan membatasi kerusakan hutan yang disebabkan oleh kebakaran. Kegiatan itu meliputi pencegahan, pemadaman dan penanganan pasca kebakaran (PP No. 45 Tahun 2004).

Desa Limbung merupakan desa yang terletak di Kecamatan Sungai Raya Kabupaten Kubu Raya yang wilayahnya sangat dekat dengan Bandar Udara Internasional Supadio. Wilayah ini adalah 
wilayah rawan bencana kebakaran hutan dan lahan. Setiap tahun kebakaran terjadi di daerah ini dikarenakan sebagian besar masyarakat masih membuka lahan dengan cara yang praktis yaitu dengan cara membakar. Menurut penelitian Akbar (2015) dan Wildayana (2006) kejadian kebakaran 95\% selalu dipicu oleh adanya pembakaran awal dalam aktivitas manusia. Selain aktivitas membuka lahan, warga kerap membakar sisa-sisa rumput kering dengan cara membakar juga, sehingga sisa-sisa pembakaran yang dibiarkan begitu saja hingga jadi meluas.Masyarakat di sekitar hutan juga berperan penting dalam upaya pencegahan kebakaran. Partisipasi aktif masyarakat diharapkan menjadi salah satu langkah pengendalian dengan dibentuknya MPA (Masyarakat Peduli Api) dibawah arahan manggala agni dengan diberikan pedoman atau acuan dalam pelatihan/penyiapan lahan tanpa bakar. Tujuan penelitian ini adalah mendeskripsikan partisipasi masyarakat Desa Limbung terhadap upaya penanggulangan kebakaran hutan dan lahan dan menjelaskan hubungan antara partisipasi masyarakat dalam penanggulangan kebakaran hutan dan lahan di Desa Limbung dengan tingkat pengetahuan, kosmopolitan, dan tingkat ketergantungan terhadap lahan.

\section{METODOLOGI PENELITIAN}

Penelitian ini dilaksanakan di Desa Limbung Kecamatan Sungai Raya Kabupaten Kubu Raya. Waktu Pengambilan data dilaksanakan pada tanggal 1 s/d 15 oktober 2018. Pengambilan sampel dilakukan secara purposive sampling, yaitu teknik penentuan sampel dengan pertimbangan tertentu. Jumlah responden yang diambil sebanyak 96 KK yang terbagi menjadi empat dusun yang ada di Desa Limbung yaitu Dusun Limbung Jaya, Dusun Merdeka, Mulyorejo, dan Sidomulyo. Pengumpulan Data yang dihasilkan dari wawancara terhadap warga dan juga menggunakan kuesioner. Guna menetukan besarnya ukuran sampel dapat dihutung dengan rumus slovin sebagai berikut:

$n i=\frac{N i}{1+\sum N i \cdot e^{2}}$

Keterangan

$\mathrm{n}=$ Sampel ke $i$

$\mathrm{N}=$ Populasi ke $i$

$\mathrm{e}=$ Batas toleransi kesalahan ( \% kesalahan)

\section{$\mathrm{I}=1$ sampai 4}

Sedangkan untuk menentukan skala skor partisipasi, analisis data yang digunakan adalah analisis teori Arnstein sebagaimana dipergunakan oleh Suciati (2006).

Tabel 1. Skala Skor Partisipasi Berdasarkan Teori Arnstein (Participation Score Scale Based On Arnstein's Theory)

\begin{tabular}{lcccccc}
\hline $\begin{array}{l}\text { Jumlah } \\
\text { Sampel }\end{array}$ & $\begin{array}{l}\text { Jumlah } \\
\text { Pertanyaan }\end{array}$ & $\begin{array}{l}\text { Skor } \\
\text { Minimum }\end{array}$ & $\begin{array}{l}\text { Skor } \\
\text { Maksimum }\end{array}$ & $\begin{array}{l}\text { Tingkat } \\
\text { Tangga } \\
\text { Arnstein }\end{array}$ & $\begin{array}{l}\text { Jarak } \\
\text { Interval }\end{array}$ & Skor \\
\hline$(1)$ & $(2)$ & $(3)$ & $(4)$ & $(5)$ & $(6)$ & $(7)$ \\
96 & 13 & $13 \times 1=13$ & $13 \times 5=65$ & 8 & $\frac{(96 \times 96=9216)-(92 \times 13=1248)}{8}$ & $1248+294$ \\
\hline \multicolumn{4}{l}{ Sumber : Hasil Olahan Data Primer 2018} & & &
\end{tabular}


$\begin{array}{lll}\text { Keterangan: } & \text { X } & \text { : Jumlah Sampel } \\ & \text { N } & \text { : Jumlah Pertanyaan } \\ & \text { STS } & \text { : Jawaban Sangat Tidak Setuju ( Bobot Skor Minimum) } \\ & \text { SS } & \text { : Jawaban Sangat Setuju (Bobot Skor Maksimum) }\end{array}$

Tabel 2. Penentuan Partisipasi Berdasarkan Teori Arnstein (Determination of Participation Based on Arnstein's Theory)

\begin{tabular}{lll}
\hline No & Tingkat Partisipasi & Skor \\
\hline 1 & Manipulasi & $1248-1541$ \\
2 & Terapi & $1542-1835$ \\
3 & Pemberitahuan & $1836-2129$ \\
4 & Konsultasi & $2130-2423$ \\
5 & Pententraman & $2424-2717$ \\
6 & Kemitraan & $2718-3011$ \\
7 & Pelimpahan Kekuasaan & $3012-3305$ \\
8 & Kontrol Masyarakat & $3306-3600$ \\
\hline
\end{tabular}

Sumber : Hasil Olahan Data Primer 2018

Analisis inferensial Kendall Tau menurut Priyatno (2010) :

$\mathrm{r}=\frac{\Sigma \mathrm{A}-\Sigma \mathrm{b}}{\mathrm{N}(\mathrm{N}-1)}$

Keterangan :

$\mathrm{r}=$ koefisien korelasi kendall tau yang besarnya $(-1<0<1)$

$\mathrm{A}=$ Jumlah rangkaian atas

$\mathrm{B}=$ Jumlah rangkaian bawah

$\mathrm{N}=$ Jumlah gagasan sampel

Rumus Uji Validitas dan Uji Validitas:

$r_{x y}=\frac{n \Sigma x y-(\Sigma x)(\Sigma y)}{\sqrt{\left\{n \Sigma x^{2}-(x)^{2}\right\}\left\{n \Sigma y^{2}-(y)^{2}\right\}}}$

Ket :

rxy $\quad=$ koefisien korelasi item-total

$\mathrm{n} \quad=$ jumlah responden $\mathrm{x} \quad=$ skor item

$\mathrm{y} \quad=$ skor total

$r_{i}=\left[\frac{k}{(k-1)}\right]\left[1-\frac{V}{(V t)}\right]$

Ket :

$r_{i}=$ reliabilitas internal seluruh komponen $\mathrm{k}$ = banyaknya pertanyaan $\mathrm{V}_{\mathrm{i}}=$ nilai varians jawaban item $\mathrm{ke}-\mathrm{i}$ $\mathrm{V}_{\mathrm{t}}=$ nilai varians total

\section{HASIL DAN PEMBAHASAN}

Berdasarkan penelitian yang dilakukan di Desa Limbung terhadap kebakaran hutan dan lahan, maka hasilnya dikelompokkan menjadi beberapa identitas. 
Tabel 3. Identitas responden menurut umur, pendidikan dan pekerjaan (Respondent's Identity According to age, education and occupation)

\section{Umur}

\begin{tabular}{ccc}
\hline Muda & Dewasa & Tua \\
$11,45 \%$ & $36,45 \%$ & $52,10 \%$ \\
\hline & Pendidikan & \\
\hline Tidak Sekolah-SD & SMP & SMA-Perguruan Tinggi \\
$19,80 \%$ & $28 \%$ & $52,08 \%$ \\
\hline & Pekerjaan & PNS \\
\hline Petani & Swasta & $6 \%$ \\
$61 \%$ & $23 \%$ & \\
Buruh & Wiraswasta & \\
$4 \%$ & $2 \%$ & \\
\hline
\end{tabular}

Identitas responden menurut kelompok umur dari 96 responden yang ada di Desa Limbung yaitu sebanyak 11 responden $(11,45 \%)$ pada umur muda, 35 responden $(36,45 \%)$ pada umur dewasa dan 50 responden $(52,10 \%)$ pada umur tua. Menurut Rakhmat (2003), menjelaskan bahwa kelompok orang tua menimbulkan pola perilaku yang pasti berbeda dengan kelompok anak-anak muda. Perbedaan usia juga mempengaruhi tingkat partisipasi masyarakat.

Identitas responden menurut kelompok pendidikan dari 96 responden yang ada di Desa Limbung yaitu sebanyak 19 responden $(19,80 \%)$ pada umur muda, 27 responden (28\%) pada umur dewasa dan 50 responden $(52,08 \%)$ pada umur tua. Menurut Litwin (1986) dalam Yulianti (2000:34) yang dikutip oleh Sutami (2009) semakin tinggi latar belakang pendidikannya, tentunya mempunyai pengetahuan yang luas tentang pembangunan dan bentuk serta tata cara partisipasi yang dapat diberikan.

Identitas responden berdasarkan jenis pekerjaan yang dominan ini terbagi menjadi 5 yaitu Petani, Buruh, PNS, Wiraswasta dan Swasta. Berdasarkan hasil olahan data dan pengamatan di lapangan di peroleh frekuensi jenis pekerjaan petani sebanyak 61 responden $(63,54 \%)$, buruh 4 responden $(4,16 \%)$, PNS 6 responden $(6,25 \%)$, wiraswasta 2 responden $(2,09 \%)$ dan swasta 23 responden $(23,96 \%)$. Jadi jenis pekerjaan yang mendominasi adalah petani dikarenakan sebagian masyarakat Desa Limbung masih memiliki lahan pribadi dan biasanya mereka tanami dengan tanaman sepertikaret, sawit (milik pribadi), jagung dan lain-lain untuk memenuhi kebutuhan hidup. 
Analisis Deskriptif

Tabel 3. Tingkat Partisipasi Masyarakat Desa Limbung (The Level Of Participation The Limbung Village Community)

\begin{tabular}{lccc}
\hline No & Kategori & Frekuensi & Persentase(\%) \\
\hline 1 & Tinggi & 2 & 2,08 \\
2 & Sedang & 31 & 32,30 \\
3 & Rendah & 63 & 65,62 \\
\hline & Jumlah & 96 & 100 \\
\hline Dari data diatas menunjukkan & masih jauh dari harapan, karena \\
bahwa tingkat partisipasi masyarakat & adanyaanggapan bahwa yang bertugas \\
Desa Limbung berada ditingkat rendah & melakukan pengawasan adalah pihak \\
(65,62\%). Dikarenakan mereka & pemerintah atau panitiapelaksana yang \\
beranggapan aparat saja sudah cukup & telah dibentuk. Sehingga ada \\
bisa untuk menangani kebakaran & kecenderungan masyarakat untuk tidak \\
tersebut dan hanya membantu jika & melakukan pengawasan. Sejalan dengan \\
kebakaran sudah meluas hingga & penelitian Yosafat (2017) Tingkat \\
menimbulkan kabut asap yang begitu & partisipasi masyarakat dapat dikatakan \\
pekat hingga berminggu-minggu. & tergolong rendah karena adanya kendala \\
Sejalan dengan Sukarjo (2006) Peran & yang berasal dari dimensi kutural \\
pengawasan yang diharapkan timbul & masyarakat yang lebih memilih tidak \\
dengan sendirinya karena perencanaan & hadir pada saat kegiatan rapat, dengan \\
dan pelaksanaandilakukan oleh & alasan kesibukan pekerjaan dan tidak \\
masyarakat sendiripun tampaknya & punya akses menuju tempat rapat.
\end{tabular}

Tabel 4. Tingkat Pengetahuan Masyarakat Desa Limbung (The Level Of Knowledge The Limbung Village Community)

\begin{tabular}{lccc}
\hline No & Kategori & Frekuensi & Persentase(\%) \\
\hline 1 & Tinggi & 59 & 61,46 \\
2 & Sedang & 36 & 37,50 \\
3 & Rendah & 1 & 1,04 \\
\hline \multicolumn{4}{c}{ Jumlah } \\
Data diatas menunjukkan bahwa & sebagai petani, sehingga tingkat \\
tingkat pengetahuan masyarakat Desa & pengetahuan tentang kebakaran dan \\
Limbung berada di tingkat tinggi & penggunaan lahannya dapat dipahami \\
sebanyak $61,46 \%$. Dikarenakan & dengan & baik.
\end{tabular}


Tabel 5. Tingkat Kosmopolitan Masyarakat Desa Limbung (The Cosmopolitan Level Of The Limbung Village Community)

\begin{tabular}{lccc}
\hline No & Kategori & Frekuensi & Persentase(\%) \\
\hline 1 & Tinggi & 59 & 61,46 \\
2 & Sedang & 36 & 37,50 \\
3 & Rendah & 1 & 1,04 \\
\hline \multicolumn{2}{c}{ Jumlah } & 96 & 100 \\
\hline Dari data diatas menunjukkan & handphone/smartphone) & untuk \\
bahwa tingkat kosmopolitan masyarakat & mengakses informasi tentang \\
Desa Limbung berada di tingkat sedang & kebarakaran atau informasi lainnya. \\
sebanyak 80,20\%. Dikarenakan warga & Terkadang anggota manggala agni turut \\
Desa Limbung sudah memanfaatkan & serta memberikan informasi kepada \\
teknologi seperti televisi, koran atau alat & warga disana. &
\end{tabular}

Tabel 6. Tingkat Ketergantungan Terhadap Lahan Masyarakat Desa Limbung (The Level Of Depencen On The Land Of The Limbung Village Community)

\begin{tabular}{lccc}
\hline No & Kategori & Frekuensi & Persentase(\%) \\
\hline 1 & Tinggi & 5 & 5,20 \\
2 & Sedang & 77 & 80,20 \\
3 & Rendah & 14 & 14,60 \\
\hline & Jumlah & 96 & 100 \\
\hline
\end{tabular}

Dari data diatas menunjukkan bahwa tingkat ketergantungan terhadap lahan masyarakat Desa Limbung berada di tingkat tinggi sebanyak $38,54 \%$. Dikarenakan masyarakat desa yang mayoritas bermata pencaharian sebagai petani sehingga warga sangat bergantung terhadap lahan disekitarnya. Ada juga warga yang menjadikan kegiatan bertani/berkebun sebagai mata pencaharian alternatif/pekerjaan sampingan.

\section{Analisis Data Menurut Teori Arnstein}

Partisipasi masyarakat menurut Cohen dan Uphoff (1977) yang dikutip Yosafat (2017) mendefinisikan partisipasi sebagai keterlibatan masyarakat mulai dari pembuatan keputusan, penerapan keputusan penikmatan hasil dan evaluasi. Apabila dibandingkan dengan tangga partisipasi dari teori Arnstein dan rumus perhitungan pada bagian metode penelitian, hasil penelitian skor yang diperoleh bahwa jumlah skor yang diperoleh dari masign-masing individu yang diteliti berjumlah 2852 dari 96 responden. Tingkat partisipasi masyarakat berada di tingkat tangga ke 6 (enam) yaitu kemitraan. Kemitraan sendiri artinya partisipasi masyarakat memiliki kekuatan untuk bernegosiasi dengan pemegang kekuasaan. Kekuatan tawar menawar pada tingkat ini adalah alat dari elit kekuasaan dan mereka yang tidak memiliki kekuasaan. Kedua pemeran tersebut sepakat untuk membagi tanggungjawab 
perencanaan dan pengambilan keputusan melalui badan kerjasama, komite-komite perencanaan, dan mekanisme untuk memecahkan kebuntuan masalah. Oleh karena itu, masyarakat hanya bekerja sama dengan pihak terkait disaat kejadian kebakaran di wilayahnya sudah parah dan pihak seperti manggala agni memerlukan bantuan dari warga sekitar.

\section{Hubungan Variabel Terikat dan Variabel Bebas}

Variabel terikat dalam penelitian ini adalah partisipasi masyarakat dalam

Tabel 7. Hasil Uji Statistik Korelasi Kendall Tau Hubungan Variabel Terikat dan Variabel Bebas(Kendall Tau correlation statistical test results relationship between dependent variables and independent variables)

\begin{tabular}{|c|c|c|c|c|c|}
\hline \multirow{2}{*}{ No } & \multirow{2}{*}{ Variabel } & \multicolumn{2}{|c|}{ Partisipasi } & \multirow{2}{*}{ Sig. (2-tailed) } & \multirow{2}{*}{ Keterangan } \\
\cline { 3 - 4 } & & $\mathbf{N}$ & Correlation Coefficient & & \\
\hline 1 & Pengetahuan & 96 & 0,092 & 0,220 & Tidak Signifikan \\
\hline 2 & Kosmopolitan & 96 & $-0,028$ & 0,712 & Tidak Signifikan \\
\hline 3 & Ketergantungan & 96 & 0,064 & 0,385 & Tidak Signifikan \\
\hline
\end{tabular}

a. Hubungan Partisipasi Masyarakat dengan Pengetahuan

Hasil uji statistik Kendall Tau antara partisipasi masyarakat terhadap penanggulangan kebakatan hutan dan lahan dengan pengetahuan masyarakat terhadap penanggulangan kebakaran hutan dan lahan diperoleh nilai Sig. (2-tailed) 0,220 lebih besar dari taraf signifikan 5\% atau nilai Sig 0,220 >0,05, dengan nilai koefisien korelasi positif 0,092. Disimpulkan tidak terdapat hubungan yang signifikan antara partisipasi dengan pengetahuan masyarakat terhadap penanggulangan kebakaran hutan dan lahan. Dikarenakan partisipasi warga yang rendah menurut hasil pengamatan di lapangan sebesar $65,62 \%$ berbanding terbalik dengan pengetahuan warga tentang penanggulangan kebakaran penanggulangan kebakaran hutan dan lahan kecamatan sungai raya kabupaten kubu raya, sedangkan variabel bebasnya adalah pengetahuan, kosmopolitan dan tingkat ketergantungan terhadap lahan. Untuk melihat hubungan antara variabel terikat dan variabel bebas, menggunkana analisis inferensial dengan menggunakan uji statistik non parametrik Kendall Tau yang terdiri dari satu variabel terikat dan tiga variabel bebas. Berikut dibawah ini adalah hasil uji statistiknya:

sebesar 61,64 \%. Warga sekitar desa limbung mayoritas berprofesi sebagai petani, walau ada yang menjadikan profesi tersebut sebagai mata pencaharian sampingan, sehingga pengetahuan warga tentang mengolah lahan dan bahaya kebakaran sudah cukup baik. Menurut wawancara dengan warga sekitar, bantuan seperti sumur bor dan mesin air yang diberikan oleh manggala agni dan pemerintah desa tidak banyak dan ada warga yang tidak tahu cara menggunakannya bahkan ada sumur bor yang tidak bisa digunakan karena rusak, atau terkadang tidak ada biaya untuk membeli bensin untuk menghidupkan mesin air, maka dari itu warga jarang berpartisipasi jika tidak ada ajakan dari pihak manggala agni. Sejalan dengan kutipan penelitian dari penelitian Listya 
(2011) yang melakukan penelitian Pengaruh Partisipasi Masyarakat Terhadap Tingkat Keberhasilan Proyek Pemberdayaan Masyarakat di Kabupaten Banyuwangi. Fenomena yang dikaji adalah penyediaan prasarana merupakan bagian terpenting dalam upaya pengembangan dan pembangunan wilayah. Tersedianya prasarana yang memadai dapat meningkatkan kegiatan sosial ekonomi, dengan kondisi sosial ekonomi yang baik masyarakat lebih memiliki kemampuan berpartisipasi dalam penyediaan prasarana di lingkungannya. Namun pada kenyataannya kemampuan pemerintah dalam menyediakan prasarana terbatas, sedang partisipasi masyarakat tidak muncul dengan sendirinya, perlu terus-menerus didorong melalui suatu komunikasi pembangunan.

\section{b. Hubungan Partisipasi Masyarakat Dengan Kosmopolitan}

Hasil uji statistik Kendall Tau antara partisipasi masyarakat terhadap penanggulangan kebakatan hutan dan lahan dengan kosmopolitan masyarakat terhadap penanggulangan kebakaran hutan dan lahan diperoleh nilai Sig. (2-tailed) 0,712 lebih besar dari taraf signifikan 5\% atau nilai Sig 0,712>0,05 dengan nilai koefisien korelasi negatif $-0,028$. Disimpulkan tidak ada hubungan yang yang signifikan antara partisipasi masyarakat dengan kosmopolitan masyarakat terhadap penanggulangan kebakaran. Sejalan dengan penelitian Hayat (1992) yang dikutip oleh Yuhana (2016) berpendapat bahwa tingkat kosmopolitan seseorang akan dapat membuat orang tersebut mampu menerima, menyaring dan menyerap informasi yang baik sehingga kemungkinan akan didapat kecendrungan yang cukup besar terjadinya perubahan pada diri mereka berdasarkan informasi tersebut. Dalam hal ini tingkat kosmopolitan tidak menentukan tidak mementukan tinggi rendahnya tingkat partisipasi pada diri seseorang karena carkawala berfikir seseorang ditentukan oleh sebesar mana informasi yang dimilikinya.

c. Hubungan Partisipasi Masyarakat Dengan Tingkat Ketergantungan Terhadap Lahan

Hasil uji statistik Kendall Tau antara partisipasi masyarakat terhadap penanggulangan kebakatan hutan dan lahan dengan tingkat ketergantungan terhadap lahan diperoleh nilai Sig. (2tailed) 0,220 lebih besar dari taraf signifikan 5\% atau nilai Sig 0,385 > 0,05, dengan nilai koefisien korelasi positif 0,064. Disimpulkan tidak ada hubungan yang signifikan antara partisipasi masyarakat dengan tingkat ketergantungan terhadap lahan. Nilai korelasi positif menunjukkan hingaa saat ini warga sangat bergantung oleh lahan yang dimilikinya yang dapat digunakan untuk keperlukan bercocok tanam/berkebun. Seperti penelitian Munir (2008) Petani pada umumnya sangat tergantung pada lahan demi mempertahankan hidupnya. Namun, tingkat ketergantungan tersebut berbedabeda sesuai kebutuhannya dalam mengolah lahan tersebut. Ada yang sepenuhnya menggantungkan hidupnya pada lahan, tetapi ada pula yang hanya menjadikan pertanian sebagai sumber 
penghasilan sampingan. Logikanya, perbedaan tingkat ketergantungan pada lahan ini akan mempengaruhi petani untuk mengkonversi lahan. Artinya, ketika petani tidak terlalu tergantung pada lahannya, kemudia nmemiliki usaha lain, kecenderungan petani tersebut untuk mengkonversi lahan lebih tinggi. Begitu juga sebaliknya, petani yang sangat tergantung pada lahannya akan berfikir berkali-kali sebelum mengkonversikan lahan mereka. Kenyataan menunjukkan hal yang berbeda yaitu pada kasus konversi lahan di Desa Candimulyo, sebagian besar petani di desa ini sangat menggantungkan hidupnya pada lahan mereka. Logikanya, ketika seorang petani tersebut sangat tergantung pada lahannya, kemungkinan petani tersebut mengkonversi lahan sangatlah kecil. Tetapi yang terjadi adalah, sebagian besar petani yang mengkonversi lahan di desa ini adalah petani yang sangat bergantung pada lahannya di bidang pertanian. Ini menunjukkan bahwa tingkat ketergantungan pada lahan ini tidak ada hubungannya dengan keputusan petani untuk mengkonversi lahan.

\section{KESIMPULAN}

Partisipasi masyarakat dalam penanggulangan kebakaran hutan dan lahan di Desa Limbung Kecamatan Sungai Raya Kabupaten Kubu Raya cenderung rendah; Partisipasi masyarakat dalam penanggulangan kebakaran hutan dan lahan dibanding dengan teori arnstein berada ditingkat 6 (enam) yaitu Kemitraan dan tidak terdapat hubungan yang signifikan dengan tingkat kosmopolitan, pengetahuan dan ketergantungan terhadap lahan.

\section{DAFTAR PUSTAKA}

Akbar. A. 2015. Studi Kearifan Lokal Penggunaan Api Persiapan Lahan. Studi Kasus di Hutan Mawas, Kalimantan Tengah. Jurnal Penelitian Sosial dan Ekonomi Kehutanan Vol. 8(3); 211-223. September 2015

Gustaav Tangel, Yosafat. 2017. Partisipasi Masyarakat Pada Program Yayasan Pitulikur Pulo Karimun jawa dan Dampaknya Terhadap Ekologi.[Skripsi]. Departemen Sains Komunikasi dan Pengembangan Masyarakat Fakultas Ekologi Manusia Institut Pertanian Bogor.

Listya. 2011. Pengaruh Partisipasi Masyarakat Terhadap Tingkat Keberhasilan Proyek Pemberdayaan Masyarakat di Kabupaten Banyuwangi. Universitas Sumatera Utara.

Munir, Misbahul. 2008. Pengaruh Konversi Lahan Pertanian Terhadap Tingkat Kesejahteraan Rumah Tangga Petani. Institut Pertanian Bogor.

Suciati. 2006. Partisipasi Masyarakat Dalam Penyusunan Rencana Umum Tata Ruang Kota Pati. [Tesis]. Magister Teknik Pembangunan Wilayah dan Kota Universitas Dipenogoro. Semarang

Sutami. 2009. Partisipasi Masyarakat Pada Pembangunan Prasarana Lingkungan Melalui Program Pemberdayaan Masyarakat Kelurahan (PPMK) Di Kelurahan Marunda Jakarta Utara. [Tesis]. Magister Teknik Pembangunan 
JURNAL HUTAN LESTARI (2019)

Vol. 7 (3) : 1130 - 1139

Wilayah dan Kota Universitas

Dipenogoro. Semarang.

Yuhana, Wiji. 2016. Partisipasi

Masyarakat Dalam Pencegahan

Kebakaran Lahan Gambut (Studi

Kasus Masyarakat Peduli Api di

Kecamatan Rasau Jaya, Kabupaten

Kubu Raya). [Skripsi]. Fakultas

Kehutanan Universitas Tanjungpura

Pontianak.

Wildayana, Elisa. 2006. Dampak

Kebakaran Hutan dan Lahan

Terhadap Sosial Ekonomi

Masyarakat di Propinsi Sumatera

Selatan. Jurnal Ilmiah HABITAT,

XVII(3):218-227, September 2006,

ISSN. 0853-5167. 